\title{
The development of a biotin deficiency in domestic fowl given wheat-based diets
}

\author{
By D. BALNAVE \\ Department of Agricultural and Food Chemistry, The Queen's University of Belfast, \\ Belfast BT9 ${ }_{5} P X$, and Department of Agriculture, Northern Ireland
}

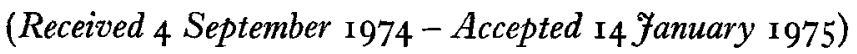

\begin{abstract}
I. Studies were done of the possible development of a biotin deficiency in domestic fowl of various ages as a result of feeding with diets composed mainly of wheat, and meat-and-bone meal. The degree of deficiency was estimated from physical symptoms, liver and kidney composition and hepatic enzyme activities.

2. Only a mild biotin deficiency developed in 3-week-old chickens and no adverse metabolic effects were found for chickens reared to 7 or 15 weeks of age or maintained for 9 months in lay on these diets, which were suspected of producing fatty liver and kidney disease in young chickens. At 3 weeks of age the deficiency was more severe the heavier the strain of chicken and the greater the rate of body-weight gain.

3. The present results question the supposition that biotin deficiency is the sole factor responsible for the development of fatty liver and kidney syndrome in young chickens.
\end{abstract}

Many nutritional factors have been suggested as being in some way responsible for the fatty liver and kidney syndrome found in immature domestic fowl. This syndrome is frequently found in growing birds when diets composed mainly of wheat, its byproducts, and meat-and-bone meal are given. Two recent reports have indicated that biotin supplementation prevents the development of this syndrome in broilers (Payne, Pearson, Gilchrist \& Shanahan, 1973; Whitehead \& Blair, 1974). The involvement of biotin has been suggested by the responses in growth rate and decreases in mortality found after biotin administration to birds fed on diets suspected of producing fatty liver and kidney syndrome. However, there is no firm evidence to substantiate the development of a biotin deficiency in these birds. Therefore, it is not yet possible to conclude definitely that biotin deficiency is the cause of the fatty liver and kidney syndrome.

Over the past decade we have carried out a number of studies of the biochemical aspects of avian biotin deficiency produced by feeding purified, biotin-free diets to birds during the first $4-5$ weeks of life. In two of these studies, fatty livers were found in biotin-deficient birds that had been fasted overnight (Balnave, I966; Balnave \& Brown, 1967). The similarity of this response to the fatty liver and kidney syndrome, combined with the development of physical symptoms of biotin deficiency in birds suffering from this syndrome, suggests that the feeding of these wheat-based diets produces a biotin deficiency in young birds.

Recent studies have shown that certain hepatic enzymes may be useful in diagnosing a biotin deficiency in young chicks (Balnave, I975; Balnave \& Jackson, I974). These enzymes were studied in the present experiments to help determine whether or not a biotin deficiency develops when wheat-based diets are fed to young birds. As the only 
Table 1. Composition of conventional diets given to chickens in the three

experiments

Ingredient $(\mathrm{g} / \mathrm{kg})$

Ground wheat

Ground maize

Meat-and-bone meal

Soya-bean meal

DL-methionine

L-lysine

Dicalcium phosphate

Limestone flour

Grass meal

Sodium chloride

Vitamins and trace minerals $\nmid$

Chemical analysis

Calculated metabolizable

energy (MJ/kg) $\ddagger$

Calculated biotin $(\mu \mathrm{g} / \mathrm{kg}) \ddagger$

Crude protein (by analysis)

$($ nitrogen $\times 6.25)(\mathrm{g} / \mathrm{kg})$

Diethyl ether extract (by

analysis) (g/kg)

\begin{tabular}{|c|c|c|}
\hline \multicolumn{3}{|c|}{ Diet } \\
\hline $\begin{array}{l}\text { Chick starter* } \\
\text { (Expts I and } 3 \text { ) }\end{array}$ & $\begin{array}{l}\text { Chick grower* } \\
\text { (Expt I) }\end{array}$ & $\begin{array}{l}\text { Layers' } \\
\text { (Expt 2) }\end{array}$ \\
\hline \multirow{2}{*}{$791 \cdot 3$} & 650.0 & 808.0 \\
\hline & $224^{\circ} 0$ & \\
\hline \multirow[t]{2}{*}{$200 \cdot 0$} & 100.0 & $105^{\circ} 0$ \\
\hline & $2 I \cdot 2$ & \\
\hline 1.4 & & $1 \cdot 0$ \\
\hline \multirow[t]{3}{*}{2.5} & & I'O \\
\hline & & $\begin{array}{l}10.0 \\
60.0\end{array}$ \\
\hline & & 10.0 \\
\hline $2 \cdot 5$ & 2.5 & $2 \cdot 5$ \\
\hline $2 \cdot 3$ & $2 \cdot 3$ & $2 \cdot 5$ \\
\hline I I $\cdot 83$ & $12 \cdot 17$ & IIX.05 \\
\hline II 5 & 106 & 105 \\
\hline 182 & 140 & 139 \\
\hline 35 & 28 & 27 \\
\hline
\end{tabular}

* Also contained a coccidiostat.

+ 'To supply $(/ \mathrm{kg})$ in chick starter and grower diets, values for layers' diet in parentheses: retinol $2.4(2.0) \mathrm{mg}$, cholecalciferol $50(82.5) \mu \mathrm{g}$, riboflavin $4(2.8) \mathrm{mg}$, cyanocobalamin $6.8(2.2) \mu \mathrm{g}, \alpha$-tocopheryl acetate $8(3 \cdot 3) \mathrm{mg}$, menaphthone $2(2 \cdot 2) \mathrm{mg}$, nicotinic acid 20 (I I) mg, pantothenic acid $8(5 \cdot 5) \mathrm{mg}$, pteroylmonoglutamic acid $0.5 \mathrm{mg}$, choline chloride 100 (Iro) $\mathrm{mg}$, iron 20 (I8) $\mathrm{mg}$, cobalt $3(3.3) \mathrm{mg}$, manganese $80(88) \mathrm{mg}$, iodine $5(2 \cdot 8) \mathrm{mg}$, zinc $70(66) \mathrm{mg}$, copper $8(8.8) \mathrm{mg}$.

$\ddagger$ Calculated from the data given by Bolton \& Blair (1974).

reports relating to wheat-based diets refer specifically to broiler stock, and since the present author has found greater difficulty in inducing a biotin deficiency in white rather than brown strains of laying-type pullets, the experiments were done using a number of different strains of birds.

\section{EXPERIMENTAL}

\section{Experiments}

Three experiments were done. In Expt I thirty-six I-d-old pullets of a White Leghorn strain were maintained in a brooder and fed on a conventional wheat-based chick starter diet, the composition of which is shown in Table I. 'This diet is similar in composition to the diet reported by Payne et al. (1973) to produce fatty liver and kidney syndrome in broilers. Calculations indicated that all basal diets used in the present study contained less biotin than the $120-145 \mu \mathrm{g}$ biotin $/ \mathrm{kg}$ diet reported by Payne, Gilchrist, Pearson \& Hemsley (1974) as being necessary to prevent fatty liver and kidney syndrome in broilers. From $16 \mathrm{~d}$ of age half the birds were maintained on the chick starter diet and the remainder were given the same diet containing biotin added at the rate of $0.30 \mathrm{mg} / \mathrm{kg}$ diet. At 7 weeks of age, eight birds from each treatment 
were killed: five birds from each treatment had received food ad lib. until slaughter and were used for hepatic enzyme assays; three were fasted for $18 \mathrm{~h}$ before slaughter and were used for liver and kidney lipid and liver fatty acid analyses.

The remainder (twenty) of the experimental birds were transferred to broiler cages and fed on a conventional wheat-based grower diet (Table I) with and without $0.30 \mathrm{mg}$ biotin/kg diet. At 15 weeks of age seven birds from each treatment were killed using the procedure described previously, except that four birds were fed ad lib. until slaughter; three were fasted for $18 \mathrm{~h}$ before slaughter.

In Expt 2 ten laying pullets of a White Leghorn strain were used. They had been fed for 9 months on a conventional layers' diet composed mainly of wheat, with meatand-bone meal as the main protein source (Table $\mathrm{I}$ ). They were maintained on this diet, with five of the birds receiving $300 \mu \mathrm{g}$ biotin orally over a period of $3 \mathrm{~d}$, a procedure which has been shown by Payne et al. (1973) to overcome biotin deficiency symptoms. The birds were killed after a further $2 \mathrm{~d}$. Birds were not fasted in this experiment as earlier studies (Balnave, 1966; Balnave $\&$ Brown, 1967) had shown that the liver lipid content and fatty acid composition of fasted, gonadal-hormone-treated pullets made deficient or rehabilitated with respect to biotin, were similar.

In Expt 3 eighteen I-d-old female chicks from each of a white broiler, a lightweight, hybrid, white laying strain and a medium-weight, hybrid, brown laying strain were kept in a brooder and fed on the same conventional wheat-based starter diet as that used in Expt $x$. From $5 \mathrm{~d}$ of age half the birds of each strain received twice weekly, by intramuscular injection, $30 \mu \mathrm{g}$ biotin in $0.5 \mathrm{ml} 0.15 \mathrm{M}-\mathrm{NaCl}$. At $2 \mathrm{I} \mathrm{d}$ of age five birds from each strain on each treatment were killed and used for hepatic enzyme assays. The remaining four birds were fasted for $18 \mathrm{~h}$ and were used for liver and kidney lipid and liver fatty acid analyses.

\section{Enzyme assays}

Livers were removed immediately and portions homogenized with 4 vol. ice-cold phosphate buffer, $\mathrm{pH} 7{ }^{\circ}$, containing $1 \mathrm{mM}$-EDTA and $7 \mathrm{~mm}-2$-mercaptoethanol. The homogenates were centrifuged at $20000 \mathrm{~g}$ for $30 \mathrm{~min}$ at $0-5^{\circ}$ and the resulting supernatant fractions were used for the estimation of enzyme activities using methods described by Balnave (1972) and Balnave \& Jackson (1974). The following enzyme activities were estimated: $\mathrm{A}^{\top} \mathrm{TP}$ citrate lyase $\left(E C_{4} \cdot \mathrm{I} \cdot 3.8\right)$, malate dehydrogenase (decarboxylating) (NADP) (EC I.I.I.40), isocitrate dehydrogenase (NADP) (EC I.1.1.42), glucose-6-phosphate dehydrogenase ( $E C$ I.I.1.49), and alanine aminotransferase $(E C$ 2.6.1.2).

Total lipid content of the liver and kidney and fatty acid composition of the liver were determined using methods previously described (Balnave \& Pearce, 1975). The results were analysed by analysis of variance. 
Table 2. Expt I. Mean body-weight and liver and kidney lipid contents for pullets (White Leghorn strain) killed at 7 and 15 weeks of age, after receiving conventional chick starter diet with (from 16-d-old) or without supplementary biotin ( $0.3 \mathrm{mg} / \mathrm{kg}$ diet) from I-d-old to 7 weeks of age and conventional wheat-based chick grower diet with or without supplementary biotin $(0.3 \mathrm{mg} / \mathrm{kg}$ diet) from $7-\mathrm{I} 5$ weeks of age

(Mean values with their standard errors; no. of birds/treatment in parentheses)

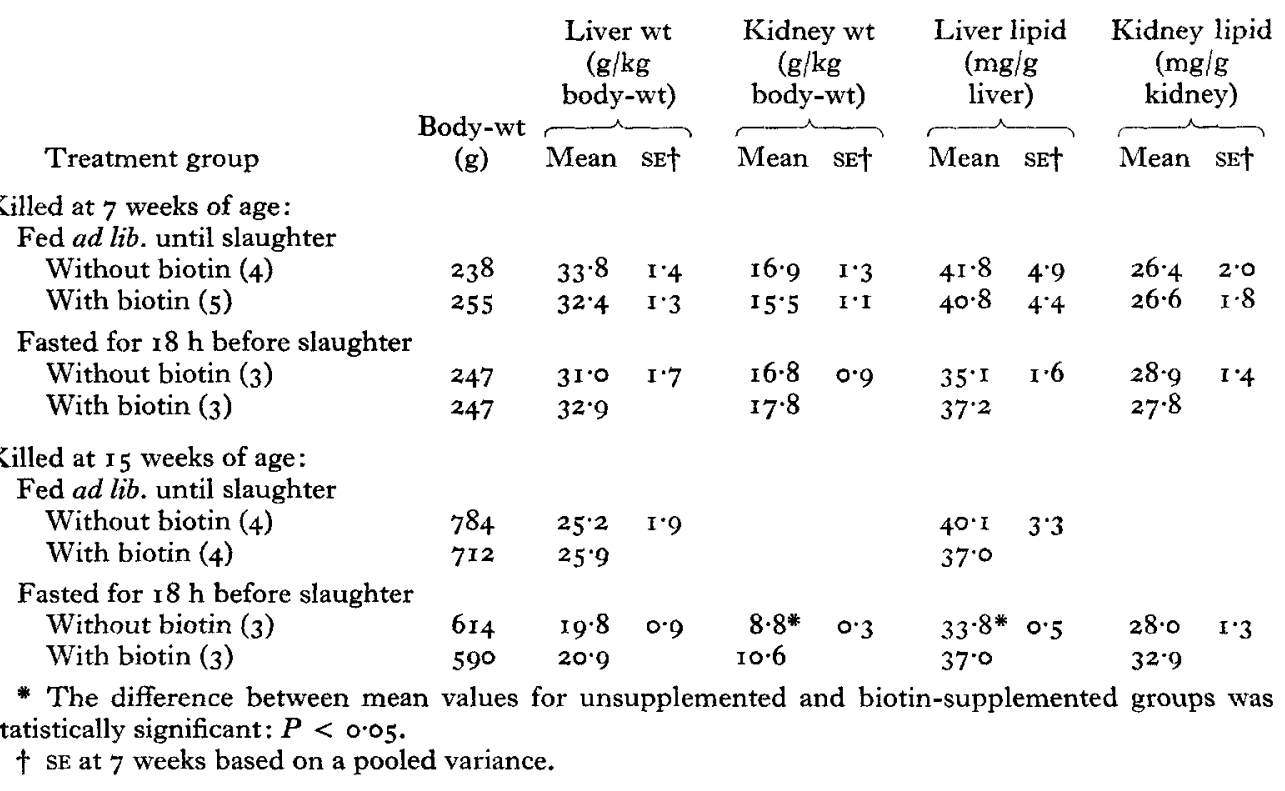

\section{RESULTS}

$\operatorname{Expt} \mathrm{I}$

Foot lesions typical of biotin deficiency became evident during the $4^{\text {th }}$ week of feeding with the conventional wheat-based chick starter diet but at no time were lesions found in the area around the beak. By the 7 th week on the unsupplemented diet these foot lesions were becoming less severe. At 15 weeks of age (having been fed the conventional chick grower diet between 7 and 15 weeks of age) no fissuring of the skin of the feet was evident but there was a high percentage of 'parrot beak' in birds given the diet without biotin supplements from $\mathrm{r}$-d-old. These lesions were not found in birds given biotin-supplemented diets.

There were no significant differences between birds fed on the biotin-supplemented and unsupplemented chick starter diet for any of the biochemical variables studied at 7 weeks of age. At 15 weeks of age the only significant treatment differences were the larger kidney weights and increased liver lipid concentrations for birds given the biotin-supplemented diets from $16 \mathrm{~d}$ of age and fasted overnight before death (Table 2). Supplementary biotin had no significant effect at either age ( 7 or 15 weeks) on the specific activities of hepatic ATP citrate lyase, malate dehydrogenase (NADP), isocitrate dehydrogenase (NADP) or glucose-6-phosphate dehydrogenase. 
Vol. 34

Avian biotin deficiency

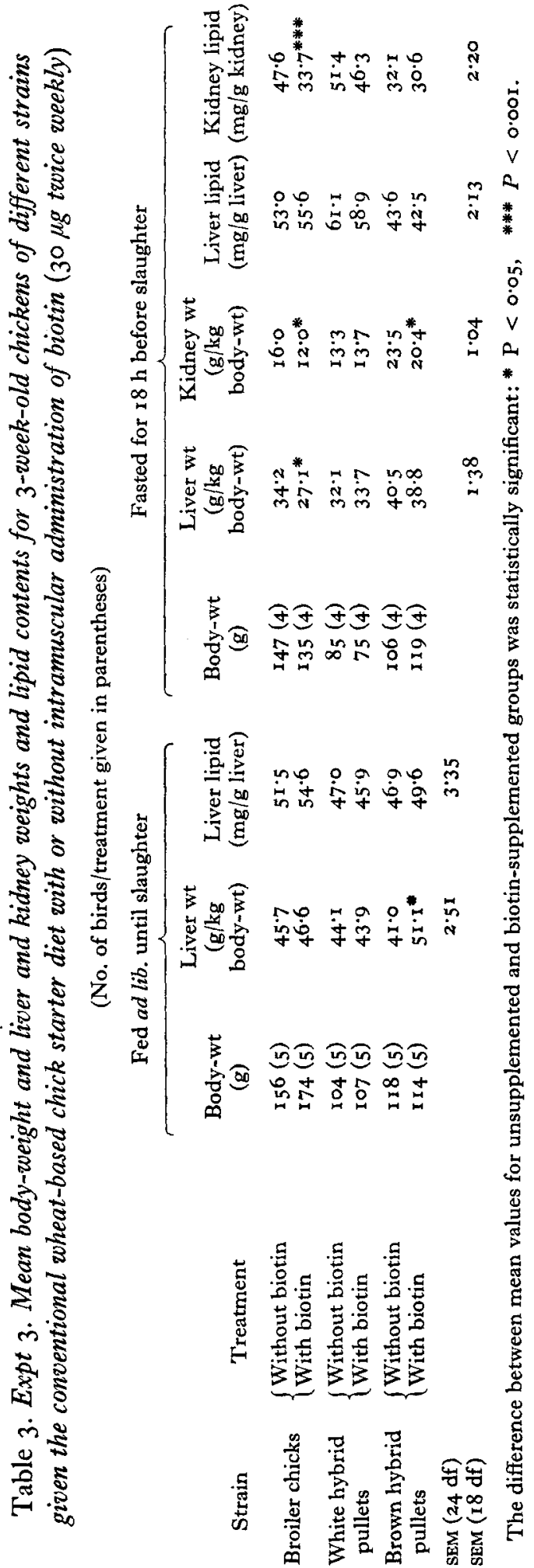


Table 4. Expt 3. Fatty acid composition of livers from fasted $\nmid$ 3-week-old chickens of different strains given the conventional wheat-based chick starter diet with or without intramuscular administration of biotin ( $3 \circ \mu \mathrm{g}$ twice weekly)

\begin{tabular}{|c|c|c|c|c|c|c|c|}
\hline \multirow[b]{2}{*}{ Strain } & \multirow[b]{2}{*}{ Diet } & \multicolumn{6}{|c|}{ Liver fatty acid composition ( $\mathrm{mmol} / \mathrm{mol})$} \\
\hline & & Palmitic & $\begin{array}{l}\text { Palmi- } \\
\text { toleic }\end{array}$ & Stearic & Oleic & Linoleic & $\begin{array}{l}\text { Arachi- } \\
\text { donic }\end{array}$ \\
\hline $\begin{array}{l}\text { Broiler } \\
\text { chicks }\end{array}$ & $\begin{array}{l}\text { Without biotin } \\
\text { With biotin }\end{array}$ & $\begin{array}{l}259 \\
277^{*}\end{array}$ & $\begin{array}{l}3^{6} \\
12^{* * *}\end{array}$ & $\begin{array}{l}190 \\
254^{* * *}\end{array}$ & $\begin{array}{l}261 \\
185^{* *}\end{array}$ & $\begin{array}{l}163 \\
162\end{array}$ & $\begin{array}{c}62 \\
101 * *\end{array}$ \\
\hline $\begin{array}{l}\text { White } \\
\text { hybrid } \\
\text { pullets }\end{array}$ & $\begin{array}{l}\text { Without biotin } \\
\text { With biotin }\end{array}$ & $\begin{array}{l}250 \\
239\end{array}$ & $\begin{array}{l}10 \\
14\end{array}$ & $\begin{array}{l}254 \\
248\end{array}$ & $\begin{array}{l}195 \\
209\end{array}$ & $\begin{array}{l}185 \\
183\end{array}$ & $\begin{array}{l}98 \\
92\end{array}$ \\
\hline $\begin{array}{l}\text { Brown } \\
\text { hybrid } \\
\text { pullets }\end{array}$ & $\begin{array}{l}\text { Without biotin } \\
\text { With biotin }\end{array}$ & $\begin{array}{l}264 \\
250\end{array}$ & $\begin{array}{l}26 \\
16\end{array}$ & $\begin{array}{l}217 \\
226\end{array}$ & $\begin{array}{l}237 \\
231\end{array}$ & $\begin{array}{l}155 \\
164\end{array}$ & $\begin{array}{l}77 \\
94\end{array}$ \\
\hline $\begin{array}{l}\text { SEM ( } 18 \\
\text { (angula } \\
\text { formati }\end{array}$ & & $3 \cdot 84$ & $9 \cdot 17$ & 5.90 & 10.49 & 8.02 & $8 \cdot 48$ \\
\hline
\end{tabular}

Statistical significance of the over-all effect of biotin administration : palmitoleic acid and arachidonic acid, $P<0.05$; stearic acid, $P<0.01$.

Statistical significance of over-all effect of strain; palmitic acid and stearic acid, $P<0.01$.

The difference between mean values for unsupplemented and biotin-supplemented groups was statistically significant: *P<0.05, **P< $<$.01, ***P<0.001.

$\dagger$ Fasted for $\mathrm{I} 8 \mathrm{~h}$ before slaughter.

Liver fatty acid compositions for fasted birds were also unaffected by supplementary biotin at either 7 or 15 weeks of age.

\section{Expt 2}

No signs of biotin deficiency were found in these birds and the only significant treatment difference found was a substantial increase in the liver lipid concentration in birds receiving the layers' diet with supplementary biotin ( $300 \mu \mathrm{g}$ orally over a $3 \mathrm{~d}$ period). Biotin had no significant effect on the specific activities of hepatic ATP citrate lyase, malate dehydrogenase (NADP), isocitrate dehydrogenase (NADP) or glucose-6-phosphate dehydrogenase.

\section{Expt 3}

Foot lesions typical of biotin deficiency were found in all birds by the 3 rd week of giving the conventional wheat-based chick starter diet. Biotin injections prevented the development of these lesions. Deficiency symptoms were first noticed in the broiler stock during the and week of the experiment. These symptoms were initially found in the brown laying stock $2-3 \mathrm{~d}$ later, and later again, to a much slighter extent, in the lighter-weight white laying stock. The fissuring of the skin of the feet became quite severe in some birds, but lesions were only found around the beak to a slight extent in two birds of the broiler stock.

Analysis of variance indicated no significant over-all effect of biotin on the liver weights of birds fed until death, although on an individual strain basis the liver weights for the brown hybrid pullets were significantly increased by biotin administration. Overall, biotin administration had significant effects on the liver and kidney weights 
for fasted birds; the liver weights for the broiler birds and the kidney weights for the broilers and brown hybrid pullets were significantly reduced.

Biotin had no significant effect on the liver lipid concentrations for fasted or fed birds of any strain. However, the kidney lipid concentrations for fasted birds of all strains were maximal in birds given the conventional unsupplemented diet but this increase was significant only for the broiler birds.

Biotin had no significant effect on the specific activities of hepatic malate dehydrogenase (NADP), glucose-6-phosphate dehydrogenase or alanine aminotransferase.

Analysis of variance indicated that biotin administration had a significant over-all effect on liver palmitoleic, stearic and arachidonic acid concentrations for fasted birds. There was a significant over-all strain effect for palmitic and stearic acid concentrations. The broiler birds were the only individual strain to show any significant effect of biotin on liver fatty acid composition. Biotin administration to the broilers significantly increased the concentrations of palmitic, stearic and arachidonic acids and significantly decreased the concentrations of palmitoleic and oleic acids.

\section{DISCUSSION}

Hepatic ATP citrate lyase and malate dehydrogenase (NADP) were analysed in the present study because previous studies (Balnave, 1975) had shown that the hepatic lipogenic capacity of the fowl, as reflected in the specific activities of these two enzymes, was substantially reduced in biotin deficiency. In addition biotin deficiency, produced by feeding a biotin-free diet to I-d-old chicks, more than doubled the specific activities of hepatic glucose-6-phosphate dehydrogenase (Balnave, 1975) and hepatic alanine aminotransferase (Balnave \& Jackson, 1974).

The present results confirm that young chicks fed on a conventional chick starter diet based primarily on wheat, with meat-and-bone meal as the principal protein source, develop biotin deficiency symptoms during the first few weeks of life. However, the evidence from the present work, when compared with results obtained using purified, biotin-free diets, suggests that these conventional diets do not induce a severe deficiency. Although the fissuring of the skin of the feet became quite severe, only in a few instances were any lesions found around the beak, and then only to a slight extent. The results of Expt I suggested that there were no physiological or enzymic effects typical of biotin deficiency at 7 weeks of age. Similarly no adverse metabolic effects were found in birds either reared to 15 weeks of age or maintained for 9 months in lay on diets suspected of producing biotin deficiency.

The results of physiological and enzymic studies in Expt 3 confirm the development of only a relatively slight biotin deficiency. They do indicate, however, that the deficiency was more severe in the broiler than the laying-type birds and that in the latter the deficiency tended to be slightly more severe in the brown hybrid pullets. This effect is probably related to the body-weight and daily rate of body-weight gain for the different strains. The values for liver fatty acid contents for fasting birds confirm that the deficiency was substantially more advanced in the broiler birds as this breed was the only one to show any significant changes in liver fatty acid composition typical of biotin deficiency (Balnave, 1966; Balnave \& Brown, 1967). 
When the results of this series of experiments are compared with those obtained from young chickens made biotin-deficient by feeding with a purified biotin-free diet from $\mathrm{I}$ or $7 \mathrm{~d}$ of age, it is apparent that although the physical symptoms of biotindeficiency are evident, as indicated for example by skin dermatitis, the metabolic changes are largely absent. For example, in the present work there was no evidence of fatty liver development for fasted chicks fed on the conventional diet and the typical effects on liver fatty acid composition for fasted chicks were only found to a limited extent in the most seriously deficient chicks. In addition any effects on the specific activities of hepatic enzymes were small and statistically not significant.

The results of the present study would make me unwilling to attribute fatty liver and kidney syndrome to a simple biotin deficiency. Under certain circumstances other factors may become important. For example, the linoleic acid contents of foods as listed by Whitehead (1972) indicate that chick diets based on wheat and meat-andbone meal would supply only about $70 \%$ of the chick's estimated daily requirement for linoleic acid. Furthermore, there is a close similarity between the dermal symptoms found in biotin-deficient and essential fatty acid-deficient chicks (Roland \& Edwards, I971), and both deficiency states induce fatty liver development and increased liver size (Balnave, 1970; Roland \& Edwards, 1971). Since biotin has been shown to cause a marked improvement in chicks suffering from fatty liver and kidney syndrome perhaps the synergistic effect of two relatively mild nutritional deficiencies is being largely offset by the provision of adequate levels of one of the limiting nutrients.

The author acknowledges the skilled technical assistance of $\mathrm{Mr} \mathrm{T}$. W. Oliver.

\section{REFERENCES}

Balnave, D. (1966). Proc. I 3 th Wld's Poult. Congr., Kiev p. 2 I 3.

Balnave, D. (1970). Wld's Poult. Sci. F. 26, 442.

Balnave, D. (1 972). Comp. Biochem. Physiol. 43 B, 999.

Balnave, D. (1975). Int. F. Biochem. 6, I7.

Balnave, D. \& Brown, W. O. (1967). Comp. Biochem. Physiol. 23, 917.

Balnave, D. \& Jackson, N. (1974). Int. F. Biochem. 5, 781.

Balnave, D. \& Pearce, J. (1975). Int. F. Biochem. 6, 25.

Bolton, W. \& Blair, R. (1974). Bull. Minist. Agric. Fish. Fd, Lond. no. 174.

Payne, C. G., Gilchrist, P., Pearson, J. A. \& Hemsley, L. A. (1974). Br. Poult. Sci. r5, 489.

Payne, C. G., Pearson, J., Gilchrist, P. \& Shanahan, K. (1973). Proc, 2nd Australian Chicken Meat and Stockfood Convention, Perth.

Roland, D. A. \& Edwards, H. M. (197 I). F. Nutr. ror, 81 r.

Whitehead, C. C. (1972). F. Sci. Fd Agric. 23, 1503.

Whitehead, C. C. \& Blair, R. (r974). Wld's Poult. Sci. F. 3o, 23 I. 